\title{
Research on Marx's International Trade Theory and the Practice of Open Economy in Shaanxi*
}

\author{
Junxia Liu \\ Business School \\ Xi'an FanYi University \\ Xi'an, China 710105
}

\author{
Jun $\mathrm{He}$ \\ Business School \\ Xi'an FanYi University \\ Xi'an, China 710105
}

\begin{abstract}
In the development process of the open economy of China, western international trade theory has been extensively spread and applied in China. However, significant problems in the development of open economy have made the western international trade theory doubted increasingly. Shaanxi serves as the bridge tower of China that opens westward. The development of export-oriented economy is badly in need of the guidance of a comprehensive international trade theory that conforms to the practical situation of Shaanxi. Marx's trade theory is the reference and criticism of the western trade theory. The combination of Marx's international trade theory and the practice of open economy of Shaanxi is an inevitable requirement for the open economy development in the new era.
\end{abstract}

Keywords-Marx's international trade theory; open economy; trade policy

\section{INTRODUCTION}

Under the deepening development of economic globalization, the international trade has increasingly promoted the integration of global resources and economic development. China has adapted to the development trend of economic globalization, and the current level of opening to the outside world enhances continuously. Comprehensively integrating in the global economy and the global value chain is a crucial strategic measure for China to better develop and greatly improve social productive forces. Opening to the outside world is an important way to develop the socialist market economy system with Chinese characteristics. The degree and achievement of opening is mainly reflected in the form of foreign trade. In the development process of the open economy of China, western international trade theory has been widely spread and applied in China. However, the practice has proved the result of the development of open economy in China under the guidance of the western international trade theory fails to solve the problem of unbalance of economic development between developed countries and China. On the contrary, because the fixed state of global value chain has been broken in the deepening development of globalization, trade war especially the trade war between America and China has intensified the complex of the international economic and political situations. Significant problems in the development of

*Fund program: This paper is the phased research fruit of the project "Research on the Modern Service Trade of the Silk Road Economic Belt" (XFU17KYTDA01). open economy make the western international trade theory doubted increasingly [1]. It is of vital importance and timely to use the correct international trade theory that is close to reality of China to measure and check foreign trade practice.

\section{LOGICAL SYSTEM AND CONTENT OF MARX'S INTERNATIONALTRADE THEORY}

Foreign trade reflects the open economy of a country. In Marxism, economic problems are not belonged to some country. It is described in The Communist Manifesto, the situation of closing the country to international intercourse and the state of self-sufficiency related to some local area or nation have disappeared. Nowadays, the interaction and interdependence between nations in many aspects have replaced it and boomed [2]. A hundred years of history has further proved the scientific judgment of Marxism. Marx has written tremendous works in his life, but he did not write any works about the international trade theory. His opinions on the international division of labor, world trade, world market, international value and trade policy are shown in his works. Therefore, Marx's international trade theory has covered the integral theoretical system that includes the production and development of international trade, its position and function, nature and rule as well as policy and measure.

\section{A. Reasons for the Production of Trade}

In Marx's international trade theory, international trade is formed by the different division of labor. The natural condition of social production is the foundation of forming the exchange of commodities and the division of labor. "Use the balance of this kind of product to exchange with people..." [3] "The initial fragmentation of society is produced in the initial largescale division of labor - the two great classes of master and slave, exploiter and the exploited..." "When production is divided into two sectors of agriculture and handicraft, production that directly aims at exchange is produced, namely commodity production. Then, the trades inside tribes and on its boundaries and the overseas trade are produced at the same time" [4]. Apparently, Marx's international trade theory thinks the different division of labor produces commodities of different properties. The scale and scope of commodity exchange expand ceaselessly, so the commodity trade between countries is formed. 


\section{B. International Division of Labor and International Exchange}

Marx has not explicitly defined the international division of labor. But Bukharin, the Marxist theorist and economist of the Soviet Union, observes except for the division of labor of other forms, the division of labor between "national economies" exists. The division labor that exceeds the boundary of "national economy" is the international division of labor. The foundation of the international exchange of commodities is the international division of labor. According to the analysis of classical authors like Marx, the position of a country in the international division of labor is mainly determined by the development level of productive forces and the situation of natural resources. To alter the adverse position in the international division of labor, developing countries must accelerate economic development and enhance labor productivity, so that they can gain more benefits in the international exchange of commodities [5].

\section{International Value Theory}

Marx established the international value theory when inspecting the world market by way of his labor value theory. "Because the bourgeoisie has exploited the world market, making the production and consumption of all countries become global...these industries process local raw materials and the raw materials that come from remote areas. Their products are consumed at home and abroad... The state of selfsufficiency and self-seclusion of local areas and countries has been replaced by the interaction of nations in various aspects and the inter-dependence of them.'[6] Marx addresses the international value is the transformation form of the country values on the world market. "Regarding value as the condensation of labor time and the materialized labor has a decisive significance on value itself." Apparently, the entity of international value refers to the universal labor consumed (congealed) in producing some commodity or the abstract human labor of the international society. Marx thinks "only foreign trade and the development of market into world market can make currency develop into world currency, and abstract labor develop into social labor". The essence of international value is the commodity exchange relation between countries reflected in the international value. In the world market, the thing that countries exchange commodities (including service) mutually on the surface is the labor contained in the commodity exchange in essence [7].

\section{The Proposal of International Trade Policy}

Marx takes much count of the role of a country in the foreign trade. His proposal of international trade policy is mainly expounded through unveiling the truth of free trade policy. Marx sharply points out: Free trade is the freedom of capital. In articles of Lecture on Free Trade and To Protect Customs Duties, Free Trade and the Working Class, Marx observes free trade has indeed brought the expansion of productivity, and the appreciation of capital is to the advantage of workers superficially. However, under the capitalist mode of production, the expansion of production and the appreciation of capital brought by free trade first mean the accumulation of capital. Undoubtedly, the appreciation and accumulation of capital lead to the blind production of larger scale and the situation that supply exceeds demand to a greater extent, then give rise to the more frequent outbreak of crisis. Free trade policy brings the continuous appreciation of capital for industrial capitalists and the increasingly furious competition and the unemployment and impoverishment caused by competition for proletarians [8]. In the article of To Protect Tariff System and Free Trade, by virtue of hard facts, Engels has proposed the Britain implements the free trade system completely to meet the objective demands of bourgeoisie in interests.

\section{PRINCIPAL CONTRADICTION BETWEEN WESTERN INTERNATIONAL TRADE THEORY AND THE DEVELOPMENT OF OPEN ECONOMY}

China has obtained significant economic development since reform and opening up. The western international trade theory has been extensively spread and applied in China. China's value of foreign trade and dependence on foreign trade have boosted enormously. The degree of economic openness has been increasingly greater. At the same time, the trade environment faced by China has becomes more and more complex. Numerous new situations and problems have appeared in foreign trade. After entering a new era, Xi Jinping has been paying high attention to issues related to the opening to the outside world of China. He addresses "the present problem is not that whether or not we should execute the opening to the outside world but that how to lift the quality of opening to the outside world and the combination of international cooperation with that of inland in the development, form new systems for opening to the outside world and develop open economies of a higher level." Under this background, problems and defects of western international trade theory have exposed in the development of foreign trade of China. Contradiction has appeared in the western international trade theory and the deepening development of open economy and has increased and been obvious continuously.

\section{A. The Countries with a High Degree of Opening Implement the Policies Contrary to the Theory}

Because western international trade theory serves the interest of bourgeoisie and promotes international trade to seek surplus profit, these countries have advocated free trade all the time. However, since the global financial crisis in 2008, developed countries headed by America have turned to trade protectionism. Protective trade measures have upgraded ceaselessly and the world economy has teetered. To get rid of the crisis, countries competitively lay their hopes on the world market, which worsens the international competition. The research of western international trade theory focuses on how to take profits through international trade. Deep level research on the economic phenomenon behind has not been done. The international trade practice of each country has more or less referred to western economics, but it is powerless in solving the inherent crisis of capitalism. This is one of the reasons why developed countries that advocate this theory implement the policies contrary to the theory. 
B. It Is Difficult for Countries with a Low Degree of Opening to Alleviate the Pressure in the Upgrade of Global Value Chain Through Theory

At present, on one hand, China need to further expand the opening to the outside world. On the other hand, the problem of excess production capacity has appeared in many fields of China, making our dependency on the world market more prominent. We "are dependent on free trade more or less". The deepening development of globalization has turned the competition between countries into the competition on the level of value chain. Whether a country can obtain benefit through participating in globalization is determined by whether it can enter the system of global value chain and enter in it in what way. In the current system of global value chain, few developed countries occupy the mid-to-high end service links for a long time, while most developing countries "share" the mid-low end production links. In the process that new technological revolution and industrial revolution promote the remodeling of global value chain, developing countries have been very difficult to enter the system of global value chain by virtue of the original advantages of cheap elements, and may even been eliminated by the system. Forging the new advantage of industry competition is becoming the "tough fight" that determines the fate of developing countries in the future economy.

The free trade advocated by western international trade theory neither makes developing countries richer and richer in the process of opening nor obviously optimizes the industrial structure. It has made the gap between developing countries and developed countries increasingly wider. The gap between the north and the south and the polarization are not narrowed but expanded further. Under the model of Global Value Chains (GVCs), developing countries are facing the dilemma of upgrade, making the world market that is extremely complicated originally mistier. Under this background, the trade policies of developing countries must be adjusted in time, or the competitive advantages are easily lost. Western international trade theory cannot correctly guide, especially fails to give a scientific explanation on the phenomenon of the unbalanced development of various international trades nowadays. The "ZTE case" that made a stir globally in 2018 has been a reflection of this phenomenon.

\section{MARX'S INTERNATIONAL TRADE THEORY AND THE PRACTICE IN THE DEVELOPMENT OF OPEN ECONOMY OF SHAANXI}

\section{A. Marx's International Trade Theory Is the Objective Demand of the Development of Open Economy of Shaanxi}

Because the open economy of China gradually turns from basing on the preponderant export strategies to actively participating in the global production system of transnational corporation, it is emphasized in the report of the 19th National Congress of the Communist Party of China that the formation of a new pattern with an overall opening must be fueled. China must emphasize the construction of "the Belt and Road Initiative" and insist on paying equal attention to bringing in and going out and follow the principle of joint discussion, joint development and sharing. Meanwhile, the openness and cooperation of innovation capacity must be strengthened to form the pattern of opening to the outside world with the land and sea cooperation internally and externally and the two-way mutual lid of the east and the west. Shaanxi has been a vital gateway of opening to the outside world in China since ancient times. The construction of "the Belt and Road Initiative" has changed the pattern of opening to the outside world in the west especially the northwest region, making Shaanxi become the leading position of opening westward [9]. The Report on the Work of the Government of Shaanxi Government in 2018 advocates more proactively integrating in the large pattern of "the Belt and Road Initiative" and accelerating the construction of a new highland related to the reform and opening-up policy. Meanwhile, it is necessary to take the development of "three economies" as the breakthrough, energetically forge the new highland and expand the new space and make efforts to make the opening to the outside world become the new advantage of pursuing and surpassing in the new era.

Scientific practice cannot do without scientific theory, which guides the practice. Shaanxi is the bridge tower of China in opening westward. The development of open economy of Shaanxi urgently needs the comprehensive guidance of scientific theory. On the basis of correctly applying western international trade theory to China, when developing the economic intercourse with the outside world, Shaanxi must be guided by the international economic contacts mentioned in the Marxist theory and cannot completely rely on the western international trade theory. Marx's international trade theory mainly inspects the capitalist society, but Marx logically regards foreign trade and world market as necessary conditions of forming history of the world, the indispensable stage of social development of human being moving from closeness to openness. Human society is still in the global stage dominated by capitalist. Therefore, Marx's international trade theory still has an important era significance and practical significance on fueling the development of open economy of Shaanxi [1]. China is a socialist country guided by Marxism. Shaanxi must guard Marxism in the economic development, which is also the objective demand of developing the open economy in Shaanxi.

\section{B. The Development of Open Economy of Shaanxi Must Keep Pace with Marx's Trade Theory}

Marx's international trade theory appears later than the western international trade theory and is the reference and criticism of western international trade theory in essence. He has dual perspectives on the free trade policy. On one hand, he reveals the essence of free trade policy is the freedom exploited by capital. On the other hand, he agrees free trade's role of historical progress in the development of the productive force and social changes. The perspective of dialectical development has provided a sharp policy weapon for China to formulate and adjust international trade policies. The economic progress achieved by China since the reform and opening up has fully proved the immense effects of free trade in promoting the progress of productivity, but the progress is accompanied by the heavy price paid my China. The dependence of China on the technologies of developed countries and expansion of the scope of international unequal exchange weaken the autonomy of China in economic independence. In the new era of China 
under the leadership of Xi Jinping, the development of open economy of Shaanxi must keep pace with Marxism theory and combine the principle of Marxism in trade with the actual conditions of the economic development in Shaanxi.

China has gradually expanded the opening-door policy to the central and western regions since the reform and opening up. The development of open economy of Shaanxi is facing more opportunities and challenges under the adjustment of national policy and the guidance of the development of new Silk Road Economic Belt. After comparing the index of economic openness, we find the level of economic openness of Shaanxi is under the mean level of China or Western China. Therefore, the development of open economy of Shaanxi must be guided by the principle of Marxism in trade. According to the physical truth of Shaanxi, we should still set about from two perspectives of bringing in and going out, better make use of the international resources and actively introduce foreign capital, advanced technologies, excellent talents and operation and management philosophy. Meanwhile, processing service, featured agriculture, competitive industries and modern service industry must go out to ensure the healthy and benign development of the open economy of Shaanxi [10] and pursue the continuous and high-quality economic growth.

\section{The Key Directions for the Development of Open Economy of Shaanxi Under the Guidance of Marx's Trade Theory}

Firstly, the government shall further optimize the business environment and remove system obstacles. According to the Doing Business released by the World Bank, the global ranking of China's degree of business convenience has risen 18 in 5 years. The rising range of it is greater in the ranking of other international organizations like World Economic Forum (WEF). However, because the opening degree of Shaanxi in China is relatively low and it is weak in the business environment, the government must vigorously optimize the business environment and make new breakthroughs on the "soft environment", in order to lift the internationalization level and overall competitiveness of Shaanxi.

Secondly, we must take full advantage of the advantages of Shaanxi in soft resources and enhance the internationalization level of the service industry. When developing the traditional industries, Shaanxi must take modern service industry as the breakthrough and make the best of resources in history, culture, tourism and science and education. Meanwhile, the innovation and coordinated development of industrial development model and the upgrade of economic transformation of Shaanxi can be promoted through determining the key fields for the development of modern service industry, taking the pilot area of comprehensive reform of the national service industry as the platform and regarding the independent innovation of the service industry as the main line.

Thirdly, we can innovate in the mode of foreign cooperation through Free Trade Zone and raise the international reputation of Shaanxi. The core of constructing Free Trade Zone is to explore the paths for the open development of industries through system innovation. Free Trade Zone is the test platform of legislation and policy for the industrial development of China. The establishment of Free
Trade Zone in Shaanxi will further raise the internationalization degree of Shaanxi and its opening degree. As an inland province, in establishing the Free Trade Zone, Shaanxi should actively learn from the experience of Shanghai Free Trade Zone and solve some problems that impede the deep opening and trade development of Shaanxi through Negative List on the practical level.

\section{CONCLUSION}

Shaanxi is the leading province of western China, with the increasingly fast pace of going out. Accelerating the transformation of development pattern and promoting the development of open economy is the primary task of economic development as well as the effective ways of executing strategy spearheaded by opening up, promoting the adjustment of industrial structure and cultivating new economic growth poles. The development of open economy of Shaanxi must guard Marxism and regard the foreign trade and the world market as indispensable stages of moving towards opening. Meanwhile, it must advance with the times and combine the principle of Marxism in trade with the actual conditions of economic development of Shaanxi and base on the position advantage of being the new start of the Silk Road Economic Belt. The communication and cooperation of talents, technologies and innovation capabilities must be focused. According to the characteristics of the industrial distribution, Shaanxi should emphatically develop modern service trades such as strategic emerging industries, high and new technology industry, financial business and international tourism and cultural exchanges.

\section{REFERENCES}

[1] Yuan Zhitian, Liu Houjun. Epochal Character and Practice of Marx's International Trade Theory - Discussion on China's Open Economy [J], Studies on Marxism, 2006(2): 22-28. (in Chinese)

[2] Marx, Engels. The Communist Manifesto [M], Beijing: People's Publishing House, August 1997: 1-82. (in Chinese)

[3] Marx. Capital (Volume 3)[M], Beijing: People's Publishing House, January 1998: 1172-1173. (in Chinese)

[4] Engels. Origin of Family, Private Ownership and Country [M], Beijing: People's Publishing House, October 1954, 155-157. (in Chinese)

[5] Zheng Baoyin, Wang Weili. Theoretical Basis that Guides the Foreign Economic Relations and Trade of China - International Economic and Trade Theory of Marxism [J], Journal of University of International Business and Economics, 1998(4): 1-9. (in Chinese)

[6] Central Compilation and Translation Bureau relevant to works of Marx, Engels, Lenin and Stalin, Selected Works of Marx and Engels (Volume 1) [M], Beijing: People's Publishing House, May 1972: 254-255. (in Chinese)

[7] Yang Shengming. Marx's International Value Theory and Issues of Sinicization [J], Economic Perspectives, 2011(8): 22-31. (in Chinese)

[8] Pan Yue. Analysis of the Perspectives of Marx and Engels on the International Trade Policies [J], Contemporary Economic Research, 2001(6): 20-25. (in Chinese)

[9] Niu Runxia. To Make Good Use of Resource Superiority of Shaanxi, To Energetically Develop "Three Economies" [N], Shaanxi Media Network - Shaanxi Daily, May 31, 2018. (in Chinese)

[10] Shaanxi Provincial Bureau of Statistics. The Development of Open Economy in Shaanxi and Thinking on Its Role in Silk Road Economic

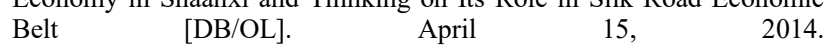


http://www.shaanxitj.gov.cn/site/1/html/126/131/138/8431.htm. Chinese) 